\title{
HHV8 ORF73 Gene
}

National Cancer Institute

\section{Source}

National Cancer Institute. HHV8 ORF73 Gene. NCI Thesaurus. Code C114488.

HHV8 ORF73, which encodes latent nuclear antigen protein, is involved in both transcriptional regulation and the inhibition of apoptosis. 